\title{
Contemporary Private Education in the Autonomous City of Ceuta: A Study on Private Religious Centres
}

\author{
Arturo Fuentes Cabrera, Arturo Manuel Fuentes Viñas \\ University of Granada, Granada, Spain \\ Email: arturofuentes@ugr.es \\ Received 14 April 2015; accepted 8 June 2015; published 11 June 2015 \\ Copyright (C) 2015 by authors and Scientific Research Publishing Inc. \\ This work is licensed under the Creative Commons Attribution International License (CC BY). \\ http://creativecommons.org/licenses/by/4.0/

c) (i) Open Access

\begin{abstract}
Over the last few centuries the Spanish education system has been characterised by the maintenance of a duality of education centres distinguished by the ownership model: public and private; the numerous studies carried out on these models have focused more on public institutions. This article attempts to analyse, from a historical and descriptive perspective, the origin and development of the private education model in the context of the autonomous city of Ceuta in the contemporary era. The investigation leading to this study has focused, fundamentally, on the educational action of the three private centres of Catholic religious ideology: Inmaculada College, San Agustín College and Sta. Maria Micaela College, which were founded at the end of the 19th century, and today have an important role in education. The study on these centres has been carried out applying the quantitative model, via the development of a series of questionnaires applied to the sectors most representative of the centres, in order to analyse the current situation, its relationships with ownership and thus to draw conclusions. A qualitative analysis has also been carried out via the Case study technique applied to each centre and the individuals responsible for their management.
\end{abstract}

\section{Keywords}

Private Education, Owners, Ideologies, Educational Action

\section{Introduction}

Private education in the Autonomous City of Ceuta has played an extremely important role in the current era, given the specific characteristics of this city, with some connotations that make it, in some cases, different to the 
rest of Spain.

This field of work has left few written traces over its existence, which makes its study all the more interesting, although it does come with a handicap to obtaining the data necessary for achieving a satisfactory result.

The study appears, a priori, complicated and unfeasible due to the scarcity of data, but there is excitement at the thought of investigating a field of work that at first, due to this lack of information appears dry, and it will be fertilised with the discovery of the facts and events surrounding this sector of education, so unknown and at the same time rich in extraordinary events and circumstances, as well as the evolution and dimensions that the topic provides from social, educational and institutional perspectives.

Firstly, a historical search of the establishment of private education has been undertaken and, secondly, an analysis of three private religious institutions, all within the context of the city in question.

Ceuta is a Spanish territory located in the north of Africa, of some $24 \mathrm{Km}^{2}$ in size, with a population of approximately 80,000 inhabitants. What to some extent defines and distinguishes this geographical space from the rest of national territory is the multicultural nature of its society, and because of this it has been defined by scholars as the phenomenon of a "cultural melting-pot". The majority of the population (60\%) is of European origin, and settled in the city independently of those who arrived after the conclusion of the Spanish Protectorate in Morocco; their defining features are not significantly different from the rest of the population of the Spanish community, subdivided into three recognised social classes: upper, middle (upper, intermediate and lower) and lower; a strong contingent of the population resides within the upper and intermediate strata of the middle class: public civil servants of the state and the autonomous city, members of the military, education professionals, traders, employees, self-employed professionals, etc. Approximately 40\% corresponds to the Arab-Muslim population, with a high number of unemployed individuals and traders with families close to the poverty line. No wonder the statistics reveal Ceuta as one of the cities with the highest poverty indexes, according to Martín \& Barceló [1].

This sociological description confirms the multicultural nature of Ceuta society, which in some way represents a number of nuances that also differentiate the school population over the last few centuries with regards to the rest of national territory, which makes the proposed study even more interesting.

This investigation study has attempted to rescue, both from the local archives and the bodies involved in education, documents that are either unpublished or have not been addressed by historians or researchers, which make reference to the motive behind this investigation. However, aware that this is not sufficient, and that in order to carry out the most complete and interesting study possible it is necessary to use other sources that are also important and clarifying, oral narrative from all sources involved has been used.

Although in the justification for the investigation we have suggested what it is that we are attempting with this study, it is worth indicating what the steps have been and what steps are to be followed in this work.

Without any doubt whatsoever, it involves a field study where the "oral narrative” from all individuals identified able to collaborate in the contribution of information is going to be an important factor in the process, all of which due to the scarce, in many cases total lack, of written information we rely on. We therefore consider this process to be a valuable, key and fundamental element.

The municipal and cathedral archives are the correct channels for seeking information from primary sources via documents. The first is selected due to the relationship that on many occasions these centres had with the municipality for requesting, in the majority of cases, economic or material aid. The second is important for gathering information relating to religious centres, as these could not operate without the prior authorisation of the prelate on duty and the approval of the bishopric authority, as will be described in the account of the origin of these centres.

Another important channel is that of the centres themselves, which are still in operation and are prime sources, and whose collaboration has been decisive in the construction of the historical account.

The compiling of all of the information from such a wide variety of sources has undoubtedly been a great challenge, despite the difficulty posed by the fact that a number of centres, along with their sponsors, no longer exist.

This study has attempted to compile all possible information from the private educational centres in the contemporary era, starting from the end of the 19th century and taking as a reference the Nuestra Señora de África College, created in 1886, with a history that is extremely dense, rich and varied in terms of its location. At present, the aforementioned centre continues to operate and is considered one of the most prestigious in the city, whereas on the other hand a great many, generally unitary in nature, have been disappearing for a number of 
different reasons. Next, the study makes reference to the centres that existed in the city in the 1920s as an express example of the appearance of private and consolidated teaching in this city.

\begin{tabular}{|c|c|c|c|}
\hline YEAR & SCHOOL & TEACHER & STREET \\
\hline \multirow{6}{*}{1923} & M. Concepcionistas College & Various & Riego \\
\hline & School for Girls & Ms Carmen Santana & Canalejas \\
\hline & School for Girls & Ms Francisca Ramos & Solís \\
\hline & School for Girls & Ms África Raga & J.L. de Torres, 87. \\
\hline & P. Agustinos College & Various & Méndez Núñez \\
\hline & Military Board of Education & Various & Méndez Núñez \\
\hline \multirow{6}{*}{1924} & Foreign School for Girls & Mr Francisco Villegas & Bda. Benítez \\
\hline & M. Concepcionistas College & Various & Riego \\
\hline & School for Girls & Ms Carmen Santana & Canalejas \\
\hline & School for Girls & Ms África Raga & J.L. de Torres \\
\hline & P. Agustinos College & Various & Méndez Núñez \\
\hline & Mixed Arabic-Spanish & Mr M. García de la Torre & Cervantes \\
\hline \multirow{11}{*}{1927} & San José Academy & Various & Ruiz Álvarez, Hadú. \\
\hline & M. Concepcionistas College & Various & Riego \\
\hline & San José de la Montaña & Various & Canalejas \\
\hline & Ángeles Custodias College & Ms Angelines Rico Mayo & Canalejas \\
\hline & P. Agustinos College & Various & Méndez Núñez \\
\hline & Mixed Arabic-Spanish & Mr M. García de la Torre & Cervantes \\
\hline & Foreign School for Girls & Mr Francisco Villegas & Bda. Benítez \\
\hline & Municipal School for Boys & Mr Alfonso Romero & Bda. La Unión \\
\hline & School for Girls & Ms Carmen Santana & Llano de las Damas \\
\hline & School for Girls & Ms Julia Campos & López Pinto \\
\hline & School for Girls & Ms África Raga & Primo de Rivera \\
\hline
\end{tabular}

Source: [2]-[11].

These schools, pioneers in the 1920s up to the present day, have given rise to many centres that have been the object of study. The investigation is carried out in two directions: on the one hand the six private education centres that currently exist, one of which goes back to the 19th century, and the others throughout the 20th. On the other hand, all smaller centres that appeared spread over the entire urban geography of the city.

Of the six large centres that today survive in the city two distinct groups must be distinguished in terms of their defining educational models: three are centres of religious ideology, whose legal and ideological statuses are defined by the different Catholic religious orders who own them, and the other three groups are defined as cooperative teaching centres, a model that came about in the 1960s in the Spanish educational system, as pointed out by Marín [12].

\section{Method}

The investigation that gives rise to this article has opted to define a general objective that address all of the aspects to develop, against the hypothesis, given the descriptive nature of the study. In short, it involves describing 
a reality in which there is an appearance of historical and current situations. Private education in a specific context, focusing the empirical and descriptive study in a determined group of educational centres: Catholic religious centres in the city.

For this study an integrating, complementary, and eclectic posture has been taken regarding the methodology, via a quantitative and qualitative analysis.

The use of the technique of the questionnaire represents a basic tool for finding out about the real situation through the individuals involved, from a quantitative point of view.

In this case, a number of surveys have been carried out on the directors of the religious entities, the teams responsible for the management of the centres and the teachers. They respond to some basic characteristics of this type of management and teaching staff, with a number of years of experience in the tasks they are entrusted with and also in the centre where they work. The majority of those surveyed hold diplomas, although the opinions of the Secondary school teachers have also been taken into account who are, on the whole, degree holders.

The survey presented to the Directors follow a multiple choice design with a Lickert scale of 1 to 4 , where 1 means totally disagree, 2 disagree, 3 agree and 4 totally agree, as we mentioned in the methodology section. It has been validated by various experts, including Manuel Lorenzo Delgado, and statistically verified with a Cronbach's Apha of 0.973 reliability.

The questionnaire presented to the Management Team follows a design of multiple choice with a single answer. It has been validated by various experts, and statistically verified with a Cronbach's Apha of 0.809 reliability.

The questionnaire presented to the teachers follows a design of multiple choice with two possible options. It has been validated by various experts, and statistically verified with a Cronbach's Apha of 0.876 reliability.

In order to complement the analysis of these centres a case study of each of them has been carried out, with the aim of creating a complete study from its beginning up to the present.

Prior to this process and in order to carry out a generalised study of the evolution of private education in the autonomous city, a deep search for written documents was undertaken in archives and those centres that continue to operate. It has been necessary to turn to the oral narrative to find sufficient information to establish the different centre models and their evolution from the end of the 19th century. In order bring this about in some cases we have been able to use primary sources (sponsors, teaching staff, former students, etc.), and in other cases secondary sources, which have in one way or another maintained some sort of relationship with these centres, which have generally ceased to exist.

\section{Results}

The results we have obtained from this study have centred on its general objective of "Discover, describe and assess the origin, development and current state of regulated private catholic education in the Autonomous City of Ceuta”. Furthermore, upon carrying out all necessary steps to obtain specific results regarding this objective, this study has achieved the following:

- Analyse the specific disciplines of the different centres in each era studied.

- Study the roots of the centres in-depth to shed light on the circumstances that gave rise to their creation.

- Discover the location of the centres created at the end of the 19th and throughout the 20th centuries.

- Analyse the original documents from the various archives in the city and from the centres themselves.

- Get closer to the personalities who have played an important role in the creation and maintenance of these centres as sources of information.

- Know through quantitative and qualitative methods the current reality of the private educational centres of a religious nature in the city of Ceuta.

In addition, on knowing results deriving from the aforementioned points, different parameters and data of relevant importance have been discovered along with important conclusions regarding these centres. Some of these conclusions are that:

- In the 1920s, many centres appeared as a result of the deficit of public centres.

- Originally, these centres lacked a particular ideology, with the exception of the religious centres, which did have one and have known how to maintain it almost entirely with the passing of time.

- The students who attended the religious centres belonged to the middle-upper class population strata, whilst the other centres were only attended by the rest of the students. 
- These centres disappeared gradually over the course of the 20th century, due to the increase in public education and the demands of the different legal legislations.

- Currently, out of the many private centres that existed in the previous century, only the religious centres remain (Los Agustinos, Las adoratrices and La Inmaculada).

- The arrival of the General Education Law of 1970 obliged all small centres to merge in order to create new institutions in accordance with the stipulations of the law, with a defined ideology.

- Currently, the centres that exist and, specifically, their owners, management teams and teaching staff, demand a greater attention to the accord they maintain with the state and greater autonomy in their running.

\section{Conclusions}

It should be pointed out that in this city during a large part of the 20th century and up to the 1970s there was a coexistence of many microcentres with unitary classrooms, with the majority being in adapted apartments. Only the religious centres have enjoyed an adequate infrastructure in order to operate correctly. All of this has been due to the scarcity of resources in the public education system.

Therefore, private education in Ceuta has played an extremely important role in the city, both for its influence in its educational development and for what it has meant for society itself.

Private education has also had a relevant role in the social life of Ceuta, a small city with a limited population, constructed in a large part during the first half of the 20th by many military and civil officials, and many other families originating from the south of Spain who arrived in the city in search of a better future than they had in their respective points of origin. These families are those who have laid down roots over the century, giving a boost to the population of the city and the workforce that to a large extent it lacked. The economic resources of civil servants and many of these families meant that their children were able to attend these types of centre, which were not free of charge until the 1970s; thus, some of the centres have been taken in different family generations since their foundation.

But the young generations are not really aware of the origin of these centres, and the difficulties involved in their founding and subsequent evolution. Regarding the small centres which covered education in the city to a large extent, over two thirds of the 20th century, there is knowledge of their existence but this knowledge is very dispersed, and on the whole originates from word of mouth. There is knowledge of the existence of centres that were legally recognised by the local and educational authorities, but a greater number operated without official recognition and, furthermore, regarding facilities the majority were private dwellings that were adapted to colleges.

We extract, in broad terms, the following conclusions:

- Private education centres in Ceuta have been important for the educational development of the city.

- The directors of the entities have confidence in their centres, their ideology, their collective strength and in the work that, day to day, is carried out therein.

- The directors of the private education centres, in the majority of cases, identify with the origins and ideals of the centre and work in accordance with their Institution.

- The teachers, to a lesser extent than the directors, work in a capacity where they are identified with the centre and adjusted to the current education systems.

- There is a demand, on the part of all members of the centres, for greater institutional support by the administration.

- Both the officially recognised centres of private education in the City of Ceuta and those of a religious nature are in a healthy state compared to those in the public domain.

\section{References}

[1] Martín Corrales, A. and Gómez Barceló, J.L. (2010) Ocho siglos de presencia catalana en Ceuta (siglos XIII-XX) [Eight Centuries of Catalan presence in Ceuta (13th-20th Centuries)]. Cuadernos de la casa de Ceuta, Barcelona.

[2] Ortega, M.L. (1917) Guía del norte de África y Sur de España en Marruecos, Cádiz-Málaga [Guide to North Afica and Souther Spain in Morocco]. Tipografía moderna. Guías internacional, Madrid.

[3] Ibero-africana-americana (1923) Anuario-Guía oficial de Ceuta [Directory-Official guide to Ceuta]. Ibero-africanaamericana, Ceuta.

[4] Ibero-africana-americana (1924) Anuario-Guía oficial de Marruecos-zona española posesiones españolas del norte de 
África y Golfo de Guinea-Gibraltar. [Directory-Official guide of Morocco-Spanish zone Spanish occupations in North Africa and the Gulf of Guinea-Gibraltar]. Ibero-africana-americana, Madrid.

[5] Ibero-africana-americana (1927) Anuario-Guía oficial de Marruecos y del África española [Directory-Official guide of Morocco and Spanish Africa]. Ibero-africana-americana, Madrid.

[6] Ibero-africana-americana (1928) Anuario guía oficial de Marruecos y del África española (comercio y turismo) [Directory-Official guide of Morocco and Spanish Africa (trade and tourism)]. Cía. Ibero-americana de publicaciones, S.A., Madrid.

[7] Baily and Ribera (1954) Anuario General de España [General Spanish Directory] (Volume IV). Bailly-Baillière and Riera, S.A., Barcelona.

[8] De la Torre Martín, M. (1958) Ceuta. Práctica guía callejera.[Ceuta. Practical Street Map]. Olimpia, Ceuta.

[9] Servicio de Publicaciones del Ayuntamiento de Ceuta (1947/1934) Guía de Ceuta.[Guide to Ceuta]. Olimpia, Ceuta.

[10] Servicio de Publicaciones del Ayuntamiento de Ceuta (1947/1934) Ceuta en la mano.[Ceuta Handbook] Anuario-Guía oficial de Ceuta [Directory-Official Guide to Ceuta]. Olimpia, Ceuta.

[11] Servicio de Publicaciones del Ayuntamiento de Ceuta (1947-48) Guía oficial de Ceuta [Official guide to Ceuta]. Olimpia, Ceuta

[12] Marín Parra, V. (2012) La educación en Ceuta: 1912-1956 [Education in Ceuta: 1912-1956]. Archivo General Ciudad Autónoma de Ceuta, Ceuta. 